\title{
Photosynthetic picoeukaryote assemblages in the South China Sea from the Pearl River estuary to the SEATS station
}

\author{
Wenxue Wu, Bangqin Huang*, Chao Zhong \\ Key Laboratory of Coastal and Wetland Ecosystems, Ministry of Education / State Key Laboratory of Marine Environmental \\ Science, Xiamen University, Xiamen 361102, PR China
}

\begin{abstract}
Photosynthetic picoeukaryotes (PPEs) can be important primary producers in the oligotrophic ocean and coastal waters at certain times of the year. In this study, we investigated the abundance and biodiversity of picoplankton, focusing on PPEs in the South China Sea (SCS) from the Pearl River estuary to SCS basin in January 2010, when the northeast monsoon prevailed. PPE abundance was quantified using fluorescent in situ hybridization associated tyramide signal amplification, and the biodiversity at 5 selected stations was determined using small subunit ribosomal RNA gene (18S rDNA) clone libraries. Our results showed that PPEs were most abundant in the Pearl River estuary (up to 8500 cells $\mathrm{ml}^{-1}$ ), and that mamiellophycean picoplanktonic green algae, such as Micromonas, Ostreococcus and Bathycoccus, showed peaks of abundance in slope or coastal waters. The $18 \mathrm{~S}$ rDNA phylogeny revealed that most of the PPEs belonged to prasinophytes, affiliating to 4 clades (Clade IX, Clade V, Clade VII, and Mamiellophyceae). Phytoplankton pigment analysis clearly showed the difference in picophytoplankton community structure along the environmental gradient provided by the selected stations. Among the PPEs, prasinophytes and prymnesiophytes accounted for 18.7 and $41.5 \%$, respectively, of the chlorophyll a biomass. Putting all the data together, we describe a complete picture of PPE assemblages along the coast-offshore gradient, showing that the prasinophytes and prymnesiophytes appear to be the key PPE components in this subtropical-tropical marginal sea.
\end{abstract}

KEY WORDS: Photosynthetic picoeukaryotes · Mamiellophyceae · FISH-TSA • 18S rDNA • Community structure $\cdot$ South China Sea

Resale or republication not permitted without written consent of the publisher

\section{INTRODUCTION}

Picophytoplankton (both prokaryotic and eukaryotic phytoplankters with cell size smaller than $3 \mu \mathrm{m}$ ) are the dominant $\mathrm{CO}_{2}$ fixation groups in oligotrophic areas of the ocean (Li 1994, Zubkov et al. 1998, Blanchot et al. 2001, Jardillier et al. 2010). Although photosynthetic picoeukaryotes (PPEs) are usually less abundant than photosynthetic prokaryotes such as the cyanobacteria Prochlorococcus and Synechococcus, PPEs can contribute significantly to phytoplankton biomass (e.g. Worden et al. 2004, Not et al. 2008).
To better understand the ecological role of PPEs, studies have been carried out at local or global scales to investigate the abundance and biodiversity of PPEs in various environments (Worden et al. 2004, Not et al. 2008, Collado-Fabbri et al. 2011, Kirkham et al. 2013).

The South China Sea (SCS) is the second largest marginal sea in the world, extending from the equator to $23^{\circ} \mathrm{N}$ and from $99^{\circ} \mathrm{E}$ to $121^{\circ} \mathrm{E}$. The northeastern SCS is connected to the western Pacific by the deep Luzon Strait. As the key exchanging channel between the semi-enclosed SCS and the 
Pacific Ocean (Shaw \& Chao 1994), the Luzon Strait is strongly affected by seasonal incursions of the Kuroshio Current (Liang et al. 2008). The surface circulation of the SCS is subjected to the strong forcing of alternating seasonal monsoons (Liu et al. 2002); the winter northeast monsoon drives a large-scale cyclonic gyre over the entire deep basin. Despite the fact that PPEs are ecologically important (Li 1994, Worden et al. 2004), little is known about their distribution and diversity in the SCS. Previous molecular phylogenetic studies have revealed diverse planktonic protists in the northern SCS and the coastal waters of the Nansha Islands (Yuan et al. 2004, Li et al. 2010). However, the sequences obtained were dominated by heterotrophic groups, and few PPE sequences were retrieved.

In this study, we focused on PPEs. Our main objectives were (1) to determine the abundance and biodiversity of the dominant PPEs in the SCS, and (2) to clarify the relationship between the PPE assemblages and the physical factors in the marginal sea. We combined fluorescent in situ hybridization associated tyramide signal amplification (FISH-TSA), 18S rRNA gene (18S rDNA) libraries, and photosynthetic pigment analyses to investigate the abundance, diversity and community composition of the picoeukaryotes.

\section{MATERIALS AND METHODS}

\section{Sampling}

Sampling was conducted at 10 stations along a transect extending from the Pearl River estuary (Stn A9) to the basin of the SCS (at the SouthEast Asia Time-series Study [SEATS] station) (Fig. 1) from 6 to 30 January 2010 on board the RV 'Dongfanghong 2'. Seawater samples were collected at 2 to 6 depths at each station using 201 Niskin bottles mounted on a rosette. Temperature and salinity profiles at each station were determined using SBE-911 CTD (Sea-Bird Electronics). The water samples were pre-filtered through $3 \mu \mathrm{m}$ pore-size polycarbonate filters (Millipore) to separate the picoplankton from larger organisms.

For FISH-TSA analysis, 75 to $200 \mathrm{ml}$ pre-filtered seawater from all 10 stations was fixed with PBS buffered paraformaldehyde (1\% final concentration) for $1 \mathrm{~h}$ at room temperature. Fixed samples were then filtered onto $0.2 \mu \mathrm{m}$ polycarbonate filters (Millipore) under $200 \mathrm{~mm} \mathrm{Hg}$ pressure. Filters were dehydrated in an ethanol series (50, 80 and 100\%, 3 min each) and stored at $-80^{\circ} \mathrm{C}$ until hybridization.
For biodiversity analysis, 3 stations (Stns A7, A1 and SEATS) were selected to represent 3 typical environments of the northern SCS: coast, slope and basin (Fig. 1). A total of 5 water samples were collected from these 3 stations: 1 from Stn A7, and 2 each from Stns A1 and SEATS: CC02A740 (Stn A7, $40 \mathrm{~m}$ ), CC02A105 (Stn A1, 5 m), CC02A175 (Stn A1, $75 \mathrm{~m}$ ), CC02SE05 (SEATS, $5 \mathrm{~m}$ ) and CC02SE75 (SEATS, $75 \mathrm{~m}$ ). More than $8 \mathrm{l}$ of pre-filtered seawater for each sample was filtered onto GF/F filters (Whatman). The filters were then frozen in liquid nitrogen and stored at $-80^{\circ} \mathrm{C}$ until analysis.

For high performance liquid chromatography (HPLC) pigment analysis, 8 to $11 \mathrm{l}$ of pre-filtered seawater from each of the 5 water samples mentioned above were filtered onto $25 \mathrm{~mm}$ GF/F filters under $200 \mathrm{~mm} \mathrm{Hg}$ pressure, and then were immediately frozen in liquid nitrogen and protected from light. In addition to the 5 pico-size samples, 2 bulk samples (Stn A1, $5 \mathrm{~m}$ and Stn A1, $75 \mathrm{~m}$ ) were collected without pre-filtration.

\section{Chlorophyll $a$ and nutrients analyses}

For the bulk chlorophyll a (chl a) analyses, 300 to $1200 \mathrm{ml}$ of un-filtered seawater samples from each of the 10 stations was filtered onto GF/F filters. Filters were extracted in $90 \%$ acetone at $-20^{\circ} \mathrm{C}$ in the dark for $24 \mathrm{~h}$, and the chl a concentrations were measured on a Turner Designs fluorometer (Trilogy 040) following Welschmeyer (1994). Nutrient concentrations (including nitrate, nitrite, silicate and phosphate) were determined using a Technicon AA3 Auto-Ana-

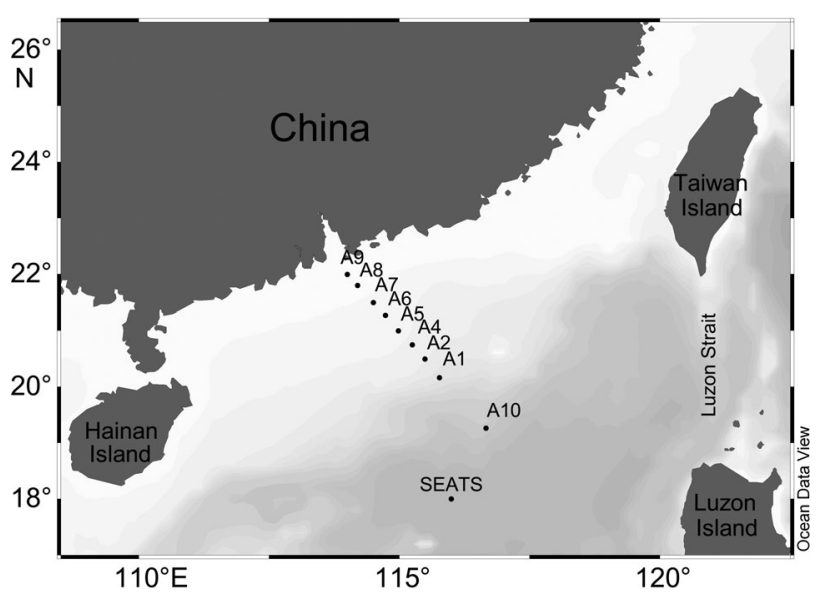

Fig. 1. Stations investigated during the CHOICE-C winter cruise in 2010. Dots correspond to stations sampled, based on their longitudes and latitudes. The sampling map was generated using Ocean Data View 4 software (Schlitzer 2011) 
Table 1. Oligonucleotide probes used in this study

\begin{tabular}{|lccc|}
\hline Probe & Sequence $\left(5^{\prime}-3^{\prime}\right)$ & Target groups & Source \\
\hline EUK1209R & GGG CAT CAC AGA CCT G & Eukaryotes & Giovannoni et al. (1988) \\
CHLO01 & GCT CCA CGC CTG GTG GTG & Chlorophyta & Simon et al. (1995) \\
NCHLO01 & GCT CCA CTC CTG GTG GTG & Non-Chlorophyta & Simon et al. (1995) \\
CHLO02 & CTT CGA GCC CCC AAC TTT & Chlorophyta & Simon et al. (2000) \\
PRAS04 & CGT AAG CCC GCT TTG AAC & Mamiellophyceae & Not et al. (2004) \\
MICRO01 & AAT GGA ACA CCG CCG GCG & Micromonas & Not et al. (2004) \\
OSTREO01 & CCT CCT CAC CAG GAA GCT & Ostreococcus & Not et al. (2004) \\
BATHY01 & ACT CCA TGT CTC AGC GTT & Bathycoccus & Simon et al. (2004) \\
PRYM02 & GGA ATA CGA GTG CCC CTG AC & Prymnesiophyceae & Simon et al. (2000) \\
PELA01 & ACG TCC TTG TTC GAC GCT & Pelagophyceae & Guillou et al. (1999) \\
BOLI02 & TAC CTA GGT ACG CAA ACC & Bolidophyceae & \\
\hline
\end{tabular}

lyzer (Bran-Lube, GmbH) onboard. The detection limits of nitrite plus nitrate $\left(\mathrm{NO}_{2}+\mathrm{NO}_{3}\right)$, silicate $\left(\mathrm{SiO}_{3}\right)$ and phosphate $\left(\mathrm{PO}_{4}\right)$ were $0.1,0.6$, and $0.08 \mathrm{mmol} \mathrm{l}^{-1}$, respectively. Nutrient data beyond the continental shelf were reported in Du et al. (2013), and data on the shelf are provided by $M$. Dai (unpubl.; mdai@xmu.edu.cn).

\section{FISH-TSA analysis}

To quantify the whole picoeukaryotic community at all 10 stations, we used a combination of a general probe (EUK1209R) and 2 probes (CHL01 and NCHL01) that specifically targeted different groups (Not et al. 2008) (Table 1). Whole cell FISH was performed following Not et al. (2002). Briefly, filters with cells were hybridized for $3 \mathrm{~h}$ at $35^{\circ} \mathrm{C}$ in the hybridization buffer (with $40 \%$ deionized formamide). After several washing procedures, TSA (PerkinElmer Las) was performed by adding $15 \mu \mathrm{l}$ TSA mix (1:1 40\% dextran sulfate and amplification diluent, 1:50 fluorescein-labeled tyramide with the mixture of dextran sulfate and amplification diluent) for $30 \mathrm{~min}$ at room temperature in the dark. To stop the enzymatic reaction, filters were washed in TNT buffer twice for $20 \mathrm{~min}$ at $55^{\circ} \mathrm{C}$. Cells were briefly rinsed in Milli-Q water and counterstained with 4',6-diamidino-2phenylindole $\left(0.5 \mu \mathrm{g} \mathrm{ml}^{-1}\right.$ final concentration) mixed with anti-fading reagent AF3 (Citifluor). Slides were then stored in the dark at $4^{\circ} \mathrm{C}$ until observation under a Nikon Eclipse 90i microscope (Nikon Instruments) within $1 \mathrm{wk}$.

\section{S rDNA libraries and phylogenetic analysis}

Genomic DNA was extracted from the water samples using the phenol:chloroform:isoamylalcohol (PCI,
Sigma) method as described in Countway et al. (2005). The DNA yield was quantified for each sample using a NanoDrop ND-1000 spectrophotometer (Nanodrop Technologies). The 18S rDNA was amplified following Not et al. (2009), using the universal eukaryotic primers Euk328f and Euk329r (Moon-van der Staay et al. 2001). Approximately $10 \mathrm{ng}$ of DNA extract was used as template in a $50 \mu \mathrm{l}$ PCR mixture containing $200 \mu \mathrm{M}$ of each dNTP, $1.5 \mathrm{mM} \mathrm{MgCl}_{2}$, $0.4 \mu \mathrm{M}$ of each primer and 1.25 U of Go-Taq Flexi DNA Polymerase (Promega) with buffer supplied with the enzyme. The thermal PCR protocol consisted of an initial denaturation step at $94^{\circ} \mathrm{C}$ for $3 \mathrm{~min}$, 35 cycles of $94^{\circ} \mathrm{C}$ for $45 \mathrm{~s}, 55^{\circ} \mathrm{C}$ for $1 \mathrm{~min}$ and $72^{\circ} \mathrm{C}$ for $3 \mathrm{~min}$, and then a final extension at $72^{\circ} \mathrm{C}$ for $10 \mathrm{~min}$. The 18S rDNA libraries were constructed using the TA cloning kit (TaKaRa) following the manufacturer's recommendations. For each library, 100 to 110 clones were sequenced with 2 sequencing reactions per clone to get the expected size of amplified fragments (ca. $1800 \mathrm{bp}$ ) using the ABI 3730xl DNA Analyzer.

Good quality sequences were analyzed with KeyDNAtools (www.keydnatools.com) for taxonomic affiliation and chimera detection. Each suspected chimera was then rechecked using BLAST (Altschul et al. 1990) with sequence segment separately. The sequences that passed chimeric screening were aligned using Clustal Omega (Sievers et al. 2011). Diversity and richness indices were calculated with Mothur (Schloss et al. 2009); the sequences were then grouped into operational taxonomic units (OTUs) using a $98 \%$ sequence similarity cut-off level based on Caron et al. (2009). Finally, the OTUs and the reference sequences were analyzed together using Gblocks (Castresana 2000), and poorly-aligned or difficult positions and divergent regions were eliminated with (1) a minimum block of 5 and (2) by allowing a gap position equal to half. Phylogenetic analyses were conducted in MEGA 5 (Tamura et al. 
2011) using maximum likelihood and applying recommended parameters from the model test in MEGA 5. Bayesian analyses were also performed using MRBAYES 3.2.1 (Huelsenbeck \& Ronquist 2001), run for one million generations and discarding the first $25 \%$ of 10000 samples as 'burn in'.

Nucleotide sequences obtained in this study were deposited in the GenBank database under accession numbers JX188276-JX188384 and KF031572KF031942.

\section{HPLC-based pigment analysis}

Phytoplankton pigments were extracted with N,Ndimethylformamide following Furuya et al. (1998). Pigment analysis was conducted using an Agilent series 1100 HPLC system fitted with a $3.5 \mu \mathrm{m}$ Eclipse $\mathrm{XDB} \mathrm{C}_{8}$ column (Agilent Technologies). Solvent A was 80:20 (v/v) methanol:ammonium acetate (1 M); solvent B was methanol; and a gradient elution procedure was used. Pigments were quantified with the standards purchased from Danish Hydraulic Institute (DHI) Water and Environment (Denmark). Based on pigment data, the phytoplankton community was determined using CHEMTAX (Mackey et al. 1996).

\section{Carbon conversion}

To estimate the importance of different groups in terms of carbon biomass, we estimated from the flow cytometry (FCM) data and FISH-TSA data the mean intracellular carbon of 4 picophytoplankton types: the cyanobacteria Synechococcus and Prochlorococcus; PPEs from the Mamiellophyceae (corresponding to Cade II of the prasinophytes, Marin \& Melkonian 2010); and non-Mamiellophyceae picoeukaryotes. The FCM data of the abundances of Synechococcus and Prochlorococcus has been reported in Chen et al. (2011). Different biomass conversion factors were used: $82 \mathrm{fg} \mathrm{C}$ cell $^{-1}$ for Synechococcus; $39 \mathrm{fg} \mathrm{C}$ cell $^{-1}$ for Prochlorococcus; and $530 \mathrm{fg} \mathrm{C}^{\mathrm{C}} \mathrm{cell}^{-1}$ for the FISHTSA-enumerated non-Mamiellophyceae picoeukaryotes (Worden et al. 2004, Cuvelier et al. 2010). For the 3 Mamiellophyceae genera detected using FISHTSA (Micromonas, Ostreococcus and Bathycoccus), a conversion factor of $237 \mathrm{fg} \mathrm{C} \mathrm{mm}^{-3}$ was used, which was based on carbon-hydrogen-nitrogen measurements of cultures (Worden et al. 2004). This factor was multiplied by the cell abundance obtained by FISH-TSA and the cell volume obtained from cell lengths. Cell lengths were obtained from Vaulot et al.
(2004): $2 \mu \mathrm{m}$ for Micromonas, $0.95 \mu \mathrm{m}$ for Ostreococcus, and $2 \mu \mathrm{m}$ for Bathycoccus. It should be noted that Micromonas biomass estimates might be overestimated, based on smaller-sized strains observed in other regions (e.g. Lovejoy et al. 2007).

\section{Statistical analyses}

The relationships between environmental parameters (temperature, salinity, nitrates, phosphates, silicate), chl $a$ and the abundances of PPEs were also analyzed. The statistical analyses were done by canonical correspondence analysis (CCA) using CANOCO 4.5.

\section{RESULTS}

\section{Environmental data}

During the sampling period, the upper $(100 \mathrm{~m})$ water column was mixed well, based on the physical and chemical parameters shown in Fig. 2. The transect was characterized by a trend of increasing surface temperature from estuary $\left(16.8^{\circ} \mathrm{C}\right)$ to basin $\left(24.7^{\circ} \mathrm{C}\right)$. Water masses with high salinity were found between the coast and basin in the upper $50 \mathrm{~m}$ of the water column. Based on the horizontal and vertical distribution of temperature and salinity, 3 distinct regions (coast, slope and basin) could be identified where the patterns of nutrients were different from their neighboring regions. Nitrate concentration ranged from below detection level $(<0.1)$ to $12.1 \mu \mathrm{mol}$ $1^{-1}$, phosphate concentration below detection level $(<0.08)$ to $0.88 \mu \mathrm{mol} \mathrm{l}^{-1}$, and silicate 0.98 to $12.96 \mu \mathrm{mol} \mathrm{l}^{-1}$. All maxima appeared at coastal Stn A9. Chl a concentration was between $0.014 \mu g \mathrm{l}^{-1}$ and $6.591 \mu \mathrm{g} \mathrm{l}^{-1}$, and its pattern matched that of the physical and chemical parameters.

\section{Picoeukaryotes abundance}

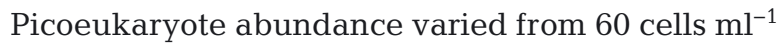
(150 m at Stn A10) to 8516 cells ml-1 (5 m at Stn A4). In spite of uniform distribution in the upper $(75 \mathrm{~m})$ water column attributed to the patterns of nutrients, relatively high abundances were obtained in the slope-especially at Stns A4 and A2 (Fig. 3). On average, chlorophytes accounted for $44 \%$ of the total abundance of picoeukaryotes measured by FISHTSA. Chlorophytes were more abundant at the slope stations (Stns A2 and A4), up to their highest abun- 

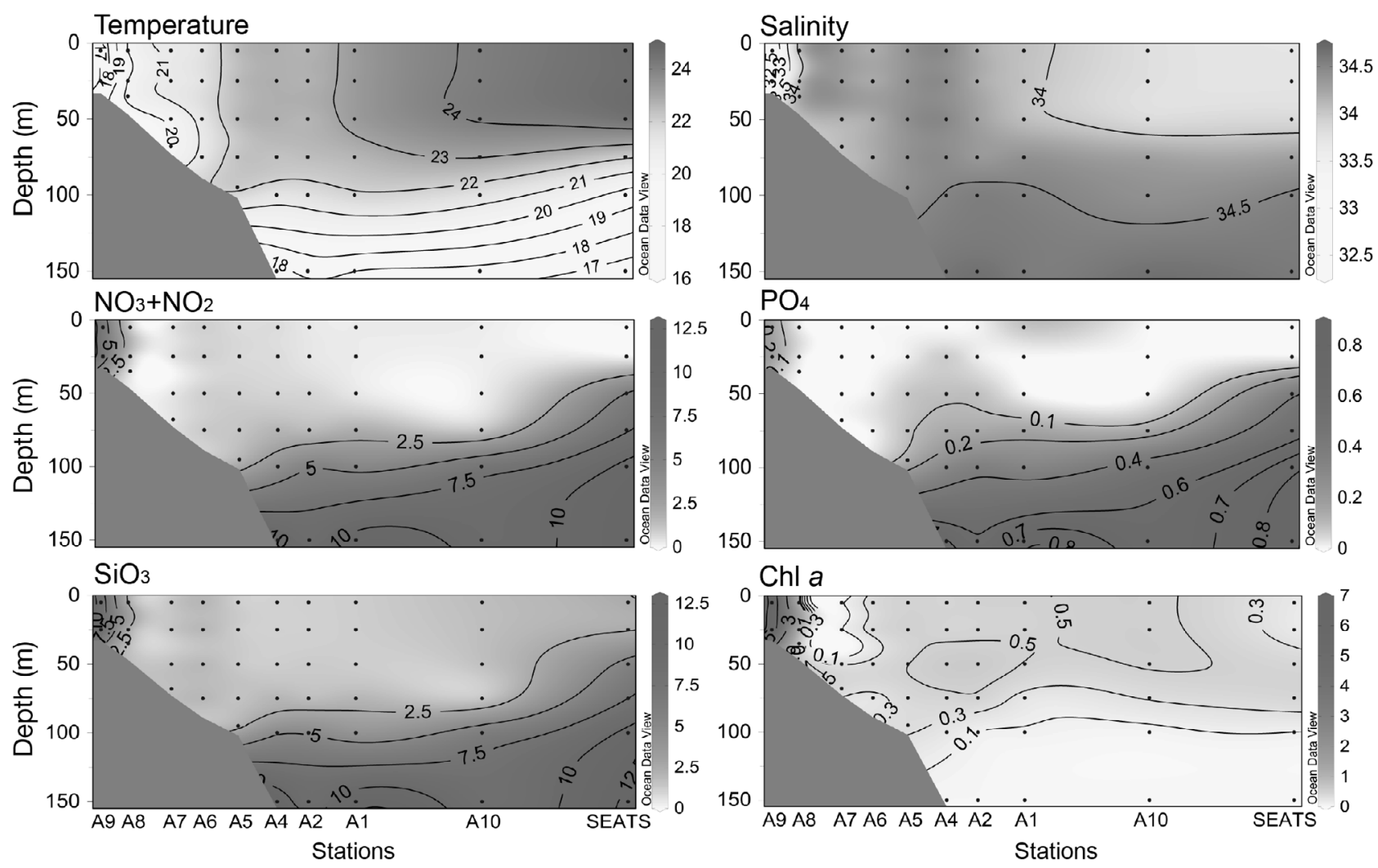

Fig. 2. Chemical and physical parameters along the sampling transect (Stns A9 to SEATS station). Contour plots indicate physical measurements - temperature $\left({ }^{\circ} \mathrm{C}\right.$ ) and salinity (PSU) - or nutrient concentrations $\mathrm{NO}_{2}+\mathrm{NO}_{3}, \mathrm{PO}_{4}$ and $\mathrm{SiO}_{3}\left(\mu m o l l^{-1}\right)$, as well as bulk chlorophyll a ( $\mathrm{chl}$ a) concentration $\left(\mu \mathrm{g} \mathrm{l}^{-1}\right)$. Nutrient data on the shelf are provided by M. Dai (unpubl.; mdai@xmu. edu.cn), and data beyond the continental shelf were reported in Du et al. (2013). Black dots represent sampling points

dance $\left(6947\right.$ cells ml $\left.^{-1}\right)$ at the surface of Stn A4, where they accounted for $82 \%$ of the total picoeukaryote abundance. In the open ocean regions (Stns A10 and SEATS), chlorophyte abundances were much lower. However, a relatively high abundance (3613 cells $\mathrm{ml}^{-1}$ ) was observed at the SEATS station at a depth of $75 \mathrm{~m}$, accounting for up to $58 \%$ of the total picoeukaryote abundance. The abundance of the other major eukaryotic lineages - the prymnesiophytes $(<1000$ cells ml $\left.{ }^{-1}\right)$, Pelagophyceae $\left(<300\right.$ cells ml $\left.^{-1}\right)$ and Bolidophyceae $\left(<600\right.$ cells ml $\left.^{-1}\right)$ - were obtained using group-specific probes. On average, they contributed $9.7 \%$ (prymnesiophytes), $1.8 \%$ (Pelagophyceae) and $2.3 \%$ (Bolidophyceae) of the total picoeukaryote abundance along this transect.

Within the chlorophytes, the contributions of 3 genera belonging to Mamiellophyceae (prasinophytes), Micromonas, Ostreococcus and Bathycoccus, were estimated. On average, Micromonas represented $8.9 \%$ of the total picoeukaryote abundance with a maximum of 1400 cells ml $^{-1}$ in slope surface water (Stn A2); Ostreococcus and Bathycoccus contributed

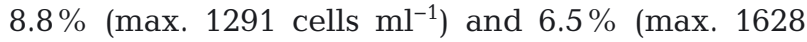

cells $\mathrm{ml}^{-1}$ ) to the total picoeukaryote abundance, with peaks observed at coastal Stn A9. Based on averages calculated from the depths sampled $(2-6 \mathrm{~m})$ at each station, the Mamiellophyceae made the greatest contribution to the total picoeukaryote abundance in different environments: the slope region for Micromonas (Stn A2, 14.5\%), coastal Stn A9 for Ostreococcus $(11.5 \%)$ and the basin region (SEATS, $10.67 \%)$ for Bathycoccus. A CCA was conducted to analyze the relationship between the PPE abundances and different environmental parameters (Fig. 4). The significant correlation between nutrient concentrations and abundances which was observed for Ostreococcus and Bathycoccus was not observed for Micromonas.

\section{Picoeukaryote 18S rDNA phylogenetic analysis}

For each of the 5 picoeukaryote 18S rDNA libraries, 86 to 106 good quality sequences were obtained ( 480 sequences in total); 24 sequences were of metazoans and were excluded from further analyses. The remaining 456 sequences (100 OTUs in total) could be 

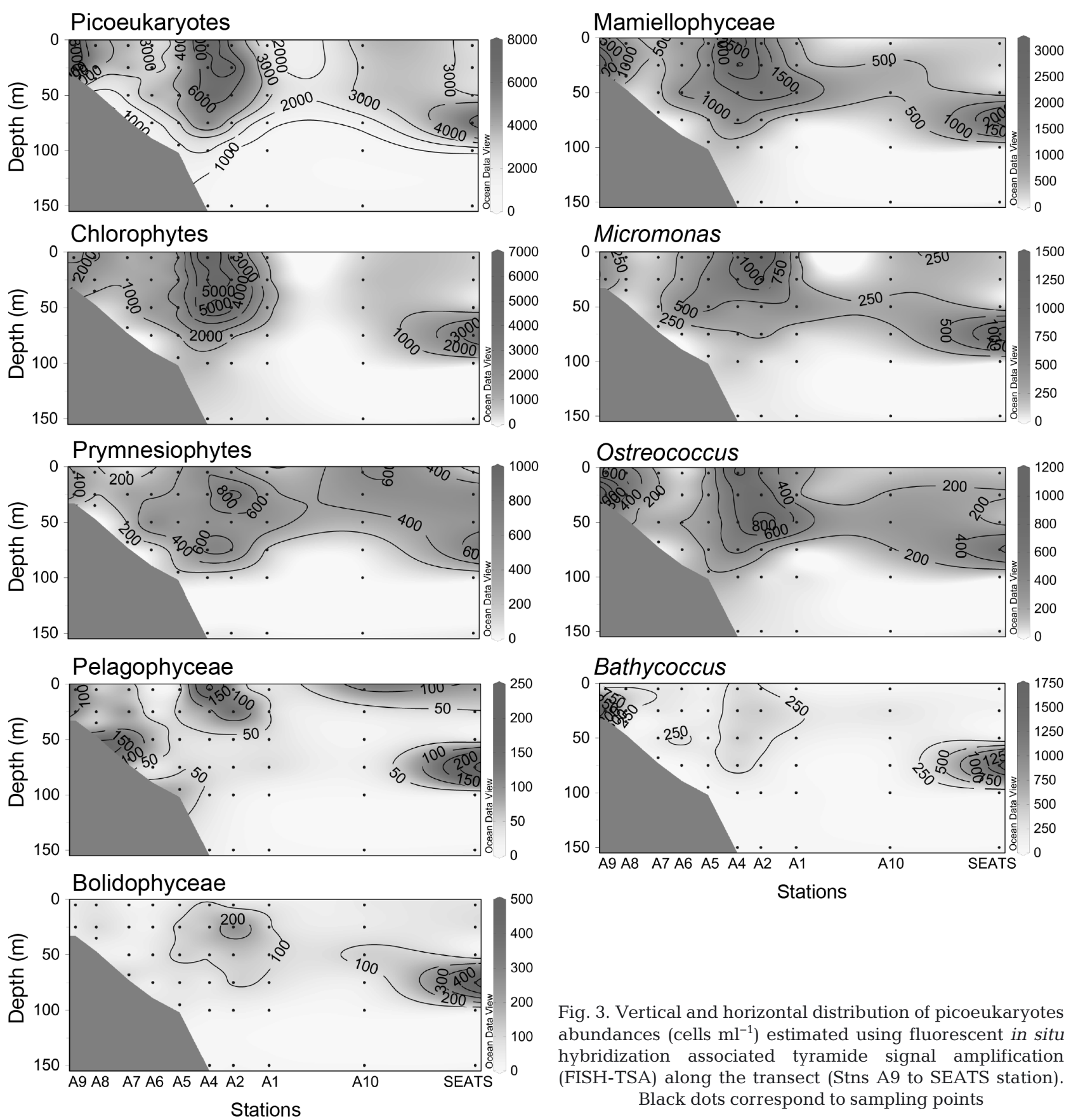

Fig. 3. Vertical and horizontal distribution of picoeukaryotes abundances (cells $\mathrm{ml}^{-1}$ ) estimated using fluorescent in situ hybridization associated tyramide signal amplification (FISH-TSA) along the transect (Stns A9 to SEATS station). Black dots correspond to sampling points

broadly grouped into 6 phylogenetic groups (alveolates group I, alveolates group II, dinoflagellates, novel marine stramenopiles (MAST), prasinophytes and radiolarians) (Fig. 5), accounting for $95.8 \%$ of the total sequences in all 5 libraries. The phylogenetic affiliation of the representative sequences of the 100 OTUs were determined using a BLAST search for each in GenBank (see Table S1 in the Supplement at www.int-res.com/articles/suppl/a071p271_supp.pdf). Sequences affiliated with the aveolates group I were most abundant in all libraries, accounting for
$>50 \%$ of the total sequences in all but 1 sample (CC02A175).

Sequences belonging to photosynthetic organisms were mostly affiliated with the prasinophytes, and these sequences could be further divided into 4 clades following Guillou et al. (2004): Clades II (Mamiellophyceae), V, VII and IX (Fig. 6). Sequences in the Mamiellophyceae clade clustered with 3 well known genera - Micromonas, Ostreococcus and Bathycoccus - with 99 to $100 \%$ similarity in nucleotide identity to the BLAST top-hit sequences from other 


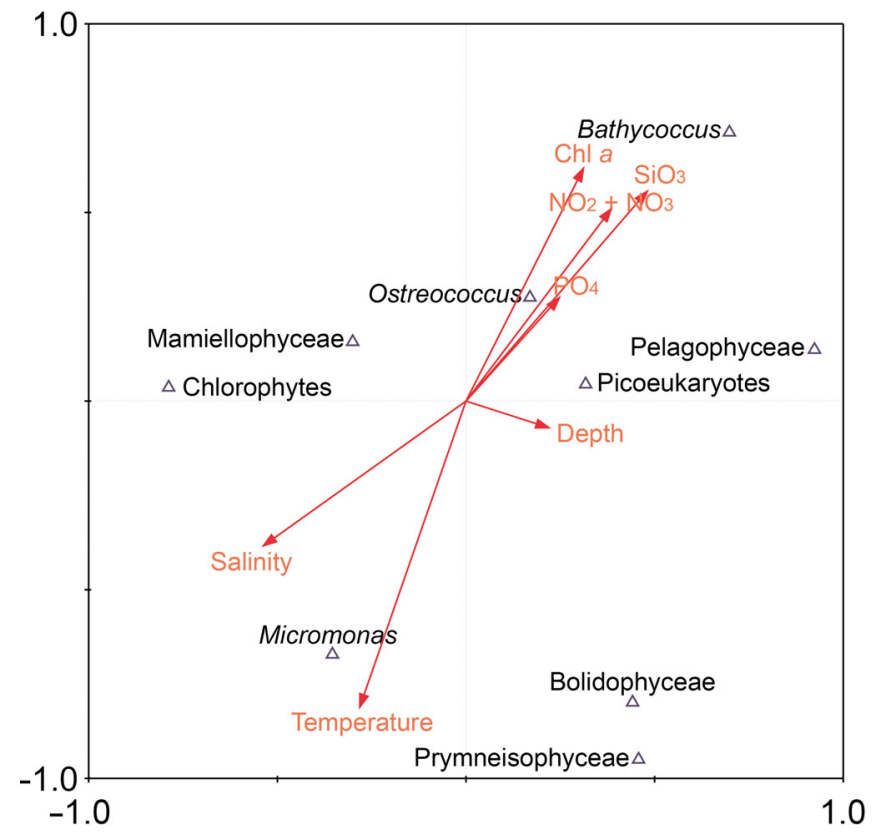

Fig. 4. Canonical correspondence analysis (CCA) plots from the fluorescent in situ hybridization associated tyramide signal amplification (FISH-TSA) results for photosynthetic picoeukaryote (PPE) abundance in relation to environmental variables. Arrows pointing in roughly the same direction indicate a highly positive correlation, arrows crossing at right angles indicate a near-zero correlation, and arrows pointing in the opposite direction have a highly negative correlation sequences were recovered from the surface pelagic water (SEATS, $5 \mathrm{~m}$ ).

\section{Picophytoplankton community structure}

The phytoplankton pigments from 7 samples were measured using HPLC in different fractions. At Stn A1, bulk total chl a (total chl a = monovinyl chl a + divinyl chl a) at the surface $\left(0.592 \mu \mathrm{g} \mathrm{l}^{-1}\right)$ was much higher than that at $75 \mathrm{~m}\left(0.207 \mu \mathrm{g} \mathrm{l}^{-1}\right)$, and the picosize fraction $(<3 \mu \mathrm{m})$ accounted for $64 \%\left(0.377 \mu \mathrm{g} \mathrm{l}^{-1}\right)$ and $30 \%\left(0.062 \mu \mathrm{g} \mathrm{l}^{-1}\right)$ of total chl $a$ at these 2 depths. At the SEATS station, the pico-size chl a at $75 \mathrm{~m}$ $\left(0.339 \mu \mathrm{g} \mathrm{l}^{-1}\right)$ was higher than at the surface $(0.218 \mu \mathrm{g}$ $\mathrm{l}^{-1}$ ), and the value at coastal Stn A7 was $0.269 \mu \mathrm{g} \mathrm{l}^{-1}$. Regarding the relative contributions of 8 major phytoplankton groups to the total chl $a$, prymnesiophytes were the dominant eukaryotic group, and a significant contribution was made by prasinophytes in different regions of this transect (Fig. 7). Prokaryotic groups (Synechococcus and Prochlorococcus) dominated the pico-phytoplankton biomass in the surface water column $(\sim 70 \%)$ at the SEATS station, but prasinoxanthin, a diagnostic pigment of prasinophytes, was not detected. From slope to coast, dominance shifted from the cyanobacteria to the eukaryotes. regions (the Pacific Ocean, the English Channel and the Indian Ocean). Clade VII sequences (67 clones) were distributed widely, and retrieved in 4 libraries. This clade could be divided into 3 sub-clades: VII-A, VII-B and VIIC (Guillou et al. 2004, Viprey et al. 2008). Clade VII sequences in our study belonged to VII-A and VII-B. Four OTUs in VII-B shared very high similarity with OLI11305, a 18S rDNA clone recovered from $75 \mathrm{~m}$ in the central South Pacific (Moon-van der Staay et al. 2001). The other sequences of VII-B were retrieved only in oceanic libraries (CC02SE05, CC02SE75), and were closest to a sequence found in high-nutrient low-chlorophyll waters of the southeast Pacific (Shi et al. 2009). For VII-A, 1 OTU clustered with previously reported sequences. Clade $\mathrm{V}$ sequences were obtained only in slope library CC02A105, whereas Clade IX
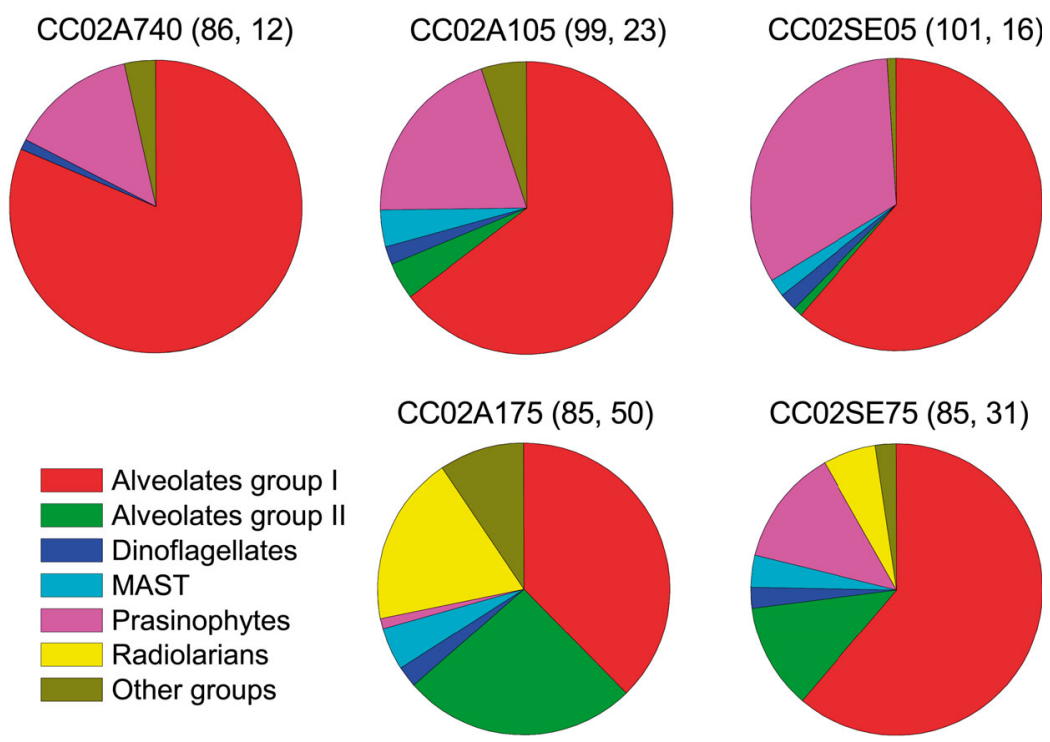

Fig. 5. Relative abundance of the 6 most represented picoeukaryote groups in the 5 clone libraries: CC02A740 (Stn A7, 40 m), CC02A105 (Stn A1, 5 m), CC02A175 (Stn A1, 75 m), CC02SE05 (SEATS, 5 m) and CC02SE75 (SEATS, $75 \mathrm{~m}$ ). The numbers in brackets after the library name are the number of sequences analyzed (former) and operational taxonomic units (OTUs) obtained (latter) in each library. MAST = novel marine stramenopiles 


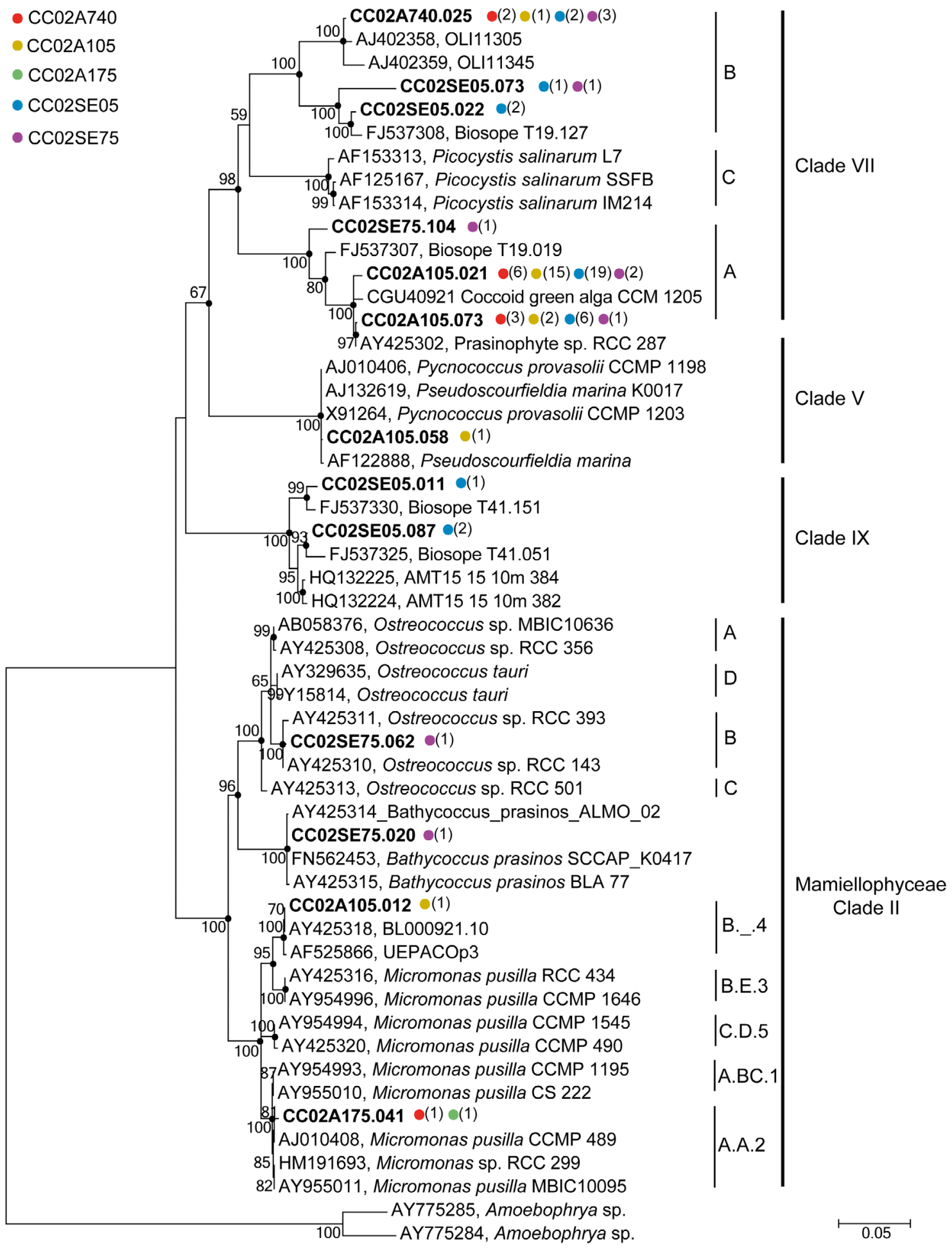

Fig. 6. Maximum-likelihood (ML) phylogenetic tree of the prasinophytes from all 5 libraries observed in the present study (bold face). Numbers in brackets indicate the numbers of clones for each phylotype retrieved in different libraries marked with color circles. The tree was constructed from 53 sequences of 1718 positions after Gblock processing. The evolutionary distances were computed using the Tamura-Nei model (gamma-distributed with invariant sites). ML bootstrap values above $50 \%$ (1000 replicates) are shown at the nodes, and Bayesian posterior probabilities higher than 0.90 are indicated with filled circles. Clade designations refer to Worden (2006) and Guillou et al. (2004). The tree was rooted using 2 Amoebophrya sequences (Amoebophrya sp. AY775284 and Amoebophrya sp. AY775285). The scale bar corresponds to 0.05 substitutions per base 


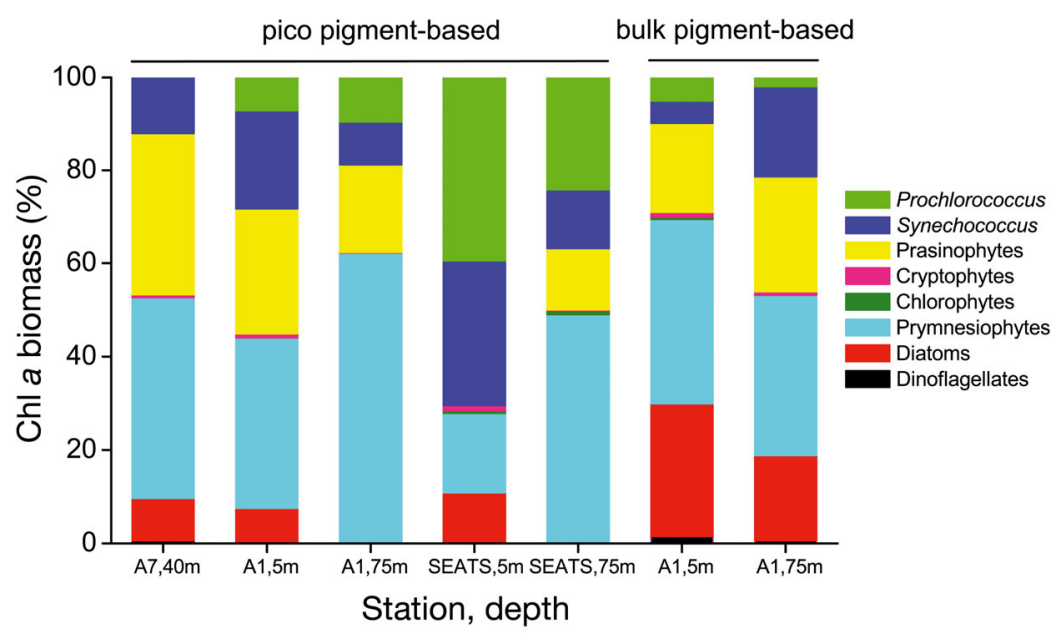

Fig. 7. Phytoplankton community composition in terms of pico-size fraction pigment (pico pigment) and bulk pigment percentage contribution of the 8 main phytoplankton groups to total chlorophyll a ( $\mathrm{chl}$ a) in the selective stations of the transect
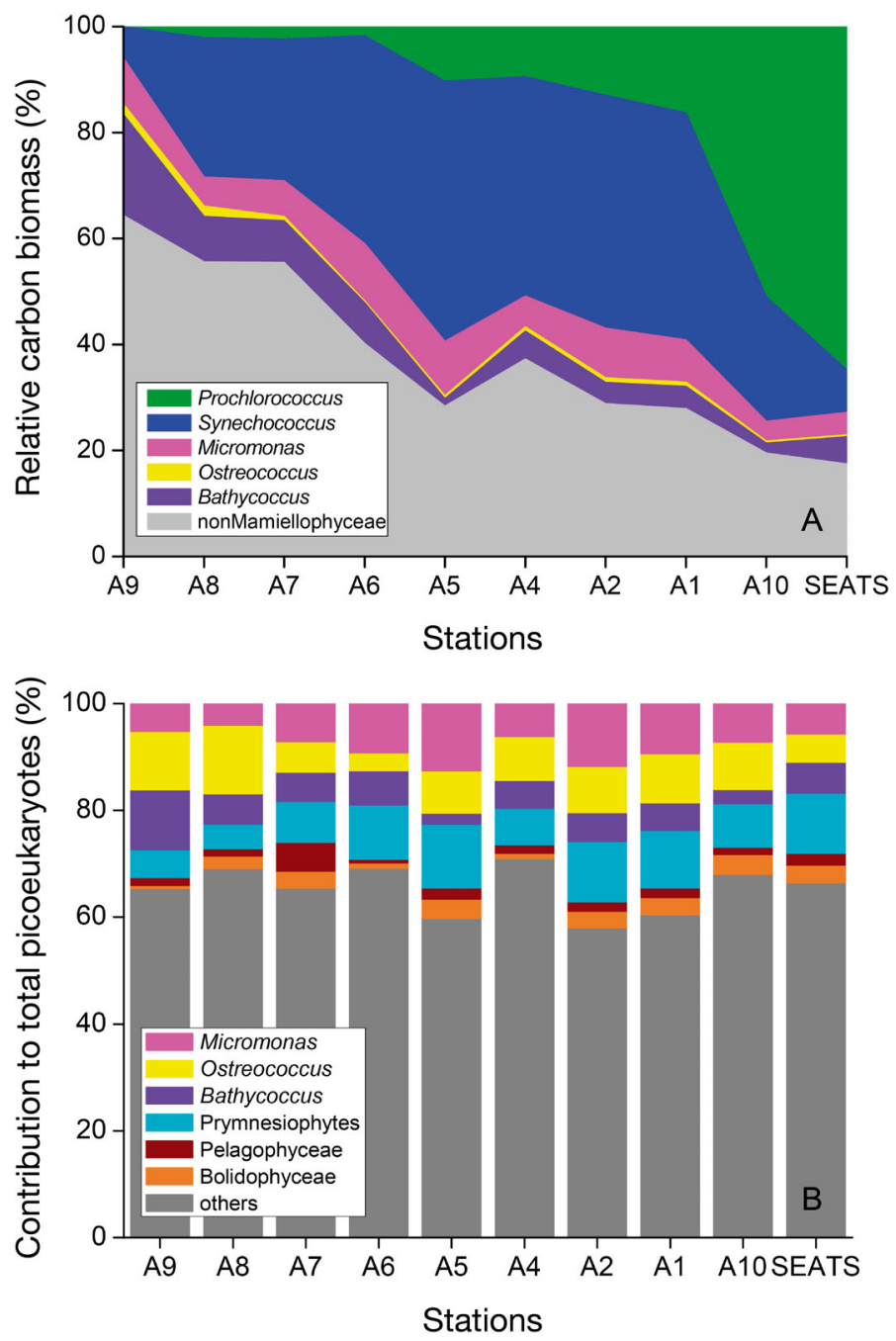

\section{Carbon biomass of different picoplankton groups}

The carbon biomass of the different picoplankton groups showed a significant pattern of relative contribution along the transect for all 10 stations (Fig. 8A). Prochlorococcus dominated over Synechococcus and the picoeukaryotes at the SEATS station, accounting for $65 \%$ of picoplanktonic carbon biomass. In contrast, Prochlorococcus was absent at coastal Stn A9, without any contribution to carbon biomass. The contribution of Synechococcus was relatively stable along the transect (on average $31 \%$ ), with 2 low values occurring at the SEATS station $(6 \%)$ and Stn A9 (8\%). Picoeukaryotes (including the Mamiellophyceae and non-Mamiellophyceae) accounted for $52 \%$ of picoplanktonic carbon biomass with a maximum of $94 \%$ at Stn A9, which contrasted significantly with that of Prochlorococcus. Among the 3 Mamiellophyceae genera, the contribution varied depending on abundance in different areas and cell size. In general, Micromonas and Bathycoccus contributed similarly to picoplanktonic carbon biomass - on average $7 \%$ and $6 \%$, respectively. Because of its smaller cell size relative to the other 2 genera, Ostreococcus contributed little to picoplankton carbon biomass, with an average of less than $1 \%$.

\section{DISCUSSION}

\section{Abundance and biodiversity of major PPEs}

In general, our FISH-TSA data showed that the distribution of PPEs was driven by various environ-

Fig. 8. (A) Relative contribution of Prochlorococcus, Synechococcus, the Mamiellophyceae (Micromonas, Ostreococcus, Bathycoccus) and the non-Mamiellophyceae (picoeukaryotes except for the Mamiellophyceae) to picophytoplankton standing stock carbon biomass (\%) along the transect. Values shown are integrated from the depths sampled. (B) Contributions of the Mamiellophyceae (Micromonas, Ostreococcus and Bathycoccus), prymnesiophytes, Pelagophyceae, Bolidophyceae and other picoeukaryotic groups to the total picoeukaryotic community estimated using fluorescent in situ hybridization associated tyramide signal amplification (FISH-TSA). The contributions are described as percentages of the total number of picoeukaryotic cells. Values are averages calculated from the depths sampled 
mental parameters (Fig. 3), and the clone libraries highlighted a considerable degree of biodiversity of the prasinophytes in different environments (Fig. 6). These 2 datasets matched well for all 5 samples. Our results confirmed that PPEs, including chlorophytes, prymnesiophytes, the Pelagophyceae and the Bolidophyceae, account for a significant fraction of the phytoplankton community in different marginal sea ecosystems.

Prasinophytes are reported to dominate the picoeukaryotic community in many waters (Not et al. 2004, 2005, 2007, Collado-Fabbri et al. 2011). A summary of the abundance of 3 genera within Mamiellophyceae estimated in different ocean regions is shown in Table 2. Within the Mamiellophyceae, species in the genus Micromonas are found to be abundant in many different areas, such as the western English Channel (Not et al. 2004), the Norwegian and Barents Seas (Not et al. 2005) and the Beaufort Sea (Balzano et al. 2012), and have even been found to bloom occasionally in the open ocean (Treusch et al. 2012). As a ubiquitous genus (Šlapeta et al. 2006), Micromonas is also present in quite distinct regions, including the southern Gulf of Mexico (Hernández-Becerril et al. 2012), the Mediterranean Sea (Marie et al. 2006), the Indian Ocean (Not et al. 2008) and the Arctic Ocean (Lovejoy et al. 2007). In our study, we also found higher abundance of Micromonas in the relatively nutrient-rich slope waters. However, unlike other reports (Not et al. 2004, Hernández-Becerril et al. 2012), Micromonas abundance was unexpectedly lower in coastal regions (Fig. 3). One possibility is that Micromonas spp., as pico-size phytoplankton, are weaker competitors compared with large-size phytoplankton such as diatoms in the eutrophic Pearl River estuary (Ning et al. 2004, Litchman et al. 2007). The Micromonas spp. sequences obtained in our study clustered with Clade IIA and II-B which included Micromonas pusilla strain RCC299, whose complete genome is available (Wor- den et al. 2009). The CCA showed a different distribution pattern of Micromonas with Ostreococcus and Bathycoccus (Fig. 4). A weak correlation between Micromonas abundance and salinity was observed in the upper $75 \mathrm{~m}$ water column $(\mathrm{n}=89, \mathrm{p}<0.05)$. A high-salinity water mass was observed on the slope, indicating possible control by the northwest Pacific (NWP) water. In the same cruise, Hu et al. (2012) reported the penetration of nonlinear Rossby eddies into the eastern part of this province, through the Luzon Strait. On the other hand, potential effects from the Kuroshio Current could also be seen, based on the observed surface and $75 \mathrm{~m}$ depth salinity (see Fig. S1 in the Supplement). NWP and Kuroshio waters are transferred by the northeast monsoon along the slope, and contain more nutrients due to vertical mixing with the SCS water. The dispersal mechanism of microbial species is important to an understanding of the ecological roles of these extremely small organisms (Finlay 2002, Fenchel \& Finlay 2004). We hypothesized that the Micromonas inhabiting this area originated from the NWP waters, taking their dispersal mechanism into account. Using the serial dilution culture method, Furuya \& Marumo (1983) observe that Micromonas was the dominant member of the phytoplankton in the Kuroshio Current. Previous studies emphasized the significant role of Micromonas at high latitude regions (Lovejoy et al. 2007, Balzano et al. 2012); however, considering the distribution patterns observed in the present study, Micromonas might also play an unexpected role in NWP waters (such as the Kuroshio Current), which are characterized by high temperature and salinity. Future study is needed to culture Micromonas under more stringently controlled conditions in the laboratory in order to determine whether the distribution we observed was due to the subtropical oceanic waters being affected by the Kuroshio Current in winter.

Table 2. Mamiellophyceae (Micromonas: Micro.; Ostreococcus: Ostreo.; Bathycoccus: Bathy.) abundances (cells ml ${ }^{-1}$ ) estimated in different ocean regions. nd = no data provided in that study

\begin{tabular}{|c|c|c|c|c|c|c|}
\hline Ocean region & Location & Method & $\begin{array}{l}\text { The high } \\
\text { Micro. }\end{array}$ & $\begin{array}{l}\text { est conce } \\
\text { Ostreo. }\end{array}$ & $\begin{array}{r}\text { tration } \\
\text { Bathy. }\end{array}$ & Source \\
\hline Chile upwelling & $36^{\circ} 30.8^{\prime} \mathrm{S}, 73^{\circ} 07.7^{\prime} \mathrm{W}$ & FISH-TSA & 9632 & 18742 & 7282 & $\begin{array}{l}\text { Collado-Fabbri et al. } \\
\text { (2011) }\end{array}$ \\
\hline San Pedro Channel & $33^{\circ} 33^{\prime} \mathrm{N}, 118^{\circ} 24^{\prime} \mathrm{W}$ & qPCR & nd & 320000 & nd & Countway \& Caron (2006) \\
\hline Western English Channel & $48^{\circ} 46^{\prime} \mathrm{N}, 3^{\circ} 57^{\prime} \mathrm{W}$ & FISH-TSA & $\sim 7000$ & $<1000$ & $<1000$ & Not et al. (2004) \\
\hline Gulf of Mexico & $\begin{array}{c}18^{\circ} 29^{\prime}-21^{\circ} \mathrm{N} \\
92^{\circ} 29^{\prime}-94^{\circ} 45^{\prime} \mathrm{W}\end{array}$ & FISH-TSA & 460 & nd & nd & $\begin{array}{l}\text { Hernández-Becerril } \\
\text { et al. (2012) }\end{array}$ \\
\hline Indian Ocean & $10^{\circ}-35^{\circ} \mathrm{S}, 15^{\circ}-120^{\circ} \mathrm{E}$ & FISH-TSA & $>750$ & $<100$ & 200 & Not et al. (2008) \\
\hline Norwegian and Barents seas & $70^{\circ}-76.5^{\circ} \mathrm{N}, 3^{\circ}-25^{\circ} \mathrm{E}$ & FISH-TSA & 9100 & nd & 2000 & Not et al. (2005) \\
\hline Northern South China Sea & $18^{\circ}-22^{\circ} \mathrm{N}, 114^{\circ}-116^{\circ} \mathrm{E}$ & FISH-TSA & 1400 & 1291 & 1628 & Present study \\
\hline
\end{tabular}


Ostreococcus is commonly reported in coastal waters in low abundance (Not et al. 2004, Zhu et al. 2005, Countway \& Caron 2006). However, a bloom lasting less than 2 wk was observed in West Neck Bay (Long Island, New York) with an abundance of $10^{5}$ cells $\mathrm{ml}^{-1}$ (O'Kelly et al. 2003). The Ostreococcus abundance observed in our study was within the range of previous reports, with relatively higher numbers recorded in the estuary and slope region (Fig. 3). This distribution might result from the special nutrient loading of the Pearl River, which flows into the northern SCS with a much smaller discharge in winter. A particularly high N:P ratio (>33) has been observed in the Pearl River estuary due to eutrophication, and Ostreococcus might be better adapted to this ecosystem than Micromonas. On the other hand, low-light adapted strains such as Ostreococcus sp. RCC143 (Rodríguez et al. 2005, DemirHilton et al. 2011) may be more abundant in the lowlight estuary - which results from good vertical mixing driven by the wind (northeast monsoon) and the resulting high turbidity, which decreases the light availability for phytoplankton growth (Harrison et al. 2008). Similarly, due to a relatively thicker mixing layer, higher abundances of Ostreococcus were present on the slope than in the basin at the SEATS station; a thicker mixing layer was also a confirmed critical factor for Ostreococcus blooms at the Bermuda Atlantic Time-series Study station (Treusch et al. 2012).

The extremely low proportion of sequences of prymnesiophytes in all 5 libraries (Table S1 in the Supplement) contrast with the revealed high diversity of this group (Fuller et al. 2006, McDonald et al. 2007, Liu et al. 2009, Kirkham et al. 2011) and the considerable contributions of prymnesiophytes to both FISH-based and HPLC-based biomass (see below for further explanation). It has been reported that higher GC content of the rDNA of the prymnesiophytes contributed to the explanation of their low proportion in clone libraries, since GC-rich genomes are difficult to amplify using universal primers (Not et al. 2008, Liu et al. 2009). In addition to the bias of primers, the relatively larger cell size of prymnesiophytes may also result in the separation of their sequences from pico-sized samples (Not et al. 2005). Interestingly, 1 of the 2 retrieved sequences of prymnesiophytes shared a similarity of $99 \%$ with the common bloom-forming alga Phaeocystis globosa in the northern SCS (Chen et al. 2002), suggesting that the high proportion of chl a biomass attributed to prymnesiophytes may be contributed by this species.

\section{Biomass contribution of PPEs}

The picophytoplankton has been recognized as an important component of the marine plankton community, contributing largely to primary productivity ( $\mathrm{Li}$ 1994, Jardillier et al. 2010) and primary producer biomass (DuRand et al. 2001). In the equatorial Atlantic, picophytoplankton contributes more than $60 \%$ to both the chl a biomass and primary production (Pérez et al. 2005). In the equatorial Pacific, picophytoplankton represents $60 \%$ of the total chl a in the surface water, and $45 \%$ in nitrate-replete waters (Mackey et al. 2002). The carbon biomass composition of the picophytoplankton community reported here was comparable to that in a previous study (Liu et al. 2007). Not surprisingly, prokaryotic groups accounted for the major part of the carbon biomass in the open ocean, similar to the relative chl a biomass contribution. However, the dominant groups were replaced by eukaryotic picophytoplankton towards the coast.

According to HPLC-based and FISH-based picophytoplankton biomass estimation, community patterns changed significantly over the large environmental gradient (Figs. 7 \& 8A). A significant chl a biomass contribution for the prasinophytes was also found based on pigments analysis. Using single layer analysis, we found that HPLC-based biomass estimation might have led to an underestimation of the Mamiellophyceae contributions in comparison with the FISH-based estimation. For example, the Mamiellophyceae accounted for 2 and $41 \%$ of the carbon biomass at the SEATS station at 5 and $75 \mathrm{~m}$ depth using FISH estimates, but only 0 and $13 \%$ in terms of the pigment-based biomass contributions. This underestimation of the Mamillophyceae may result from a failure to detect small amounts of prasinoxanthin and uriolide in the extant prasinophyceans in the field (Not et al. 2007). The relative contribution of the Mamiellophyceae to total picoeukaryotic community standing stock carbon biomass was also lower than the contribution to total picoeukaryotes in terms of cell abundances (Fig. 8B). This is probably a consequence of the slightly smaller size of Mamiellophyceae compared with other picoeukaryotes, such as the prymnesiophytes (Not et al. 2005). Moreover, sequences of Clade VII lacking prasinoxanthin were retrieved frequently (Fig. 6) (Latasa et al. 2004), indicating that the relative contribution of all prasinophytes to chl a biomass might also be underestimated.

In the present study, HPLC pigment analysis suggested that the prymnesiophytes are an important component of the PPE community in all 5 samples. The importance of the chl a biomass contribution of 
prymnesiophytes to the picophytoplankton has also been observed in most mesotrophic and oligotrophic waters (Moon-van der Staay et al. 2000, Cuvelier et al. 2010). In particular, prymnesiophytes contribute a large fraction (30 to $40 \%$ ) of the chl a biomass in the upper layers of the water column of the equatorial Pacific (Mackey et al. 1998). Moreover, a significant contribution of small prymnesiophytes to primary productivity has been observed in the subtropical and tropical northeast Atlantic Ocean (Jardillier et al. 2010). It has been reported that mixotrophy occurs in some species of prymnesiophytes containing chloroplasts (Green 1991), suggesting that they can obtain energy via bacterivory (Zubkov \& Tarran 2008). As an oligotrophic body of water in the western Pacific, the SCS is characterized by nutrient limitation (Chen et al. 2004), including the coastal waters affected by the Pearl River (Xu et al. 2008). The mixotrophic prymnesiophytes might be significantly more competitive than purely phototrophic groups such as prasinophytes, and this contributes to the explanation of its high proportion of chl a biomass based on 19'-hexanoyloxyfucoxanthin.

Traditionally, large phytoplankton such as diatoms are believed to control carbon flux from the surface ocean (Michaels \& Silver 1988). Due to their small sizes, the sinking of picophytoplankton (such as the widespread Mamiellophyceae) is believed to be extremely slow. However, these small cells can be incorporated into large aggregates or rapidly-sinking fecal pellets of organisms at high trophic levels (e.g. Richardson \& Jackson 2007). We suggest in our integrated study that picoeukaryotic phytoplankton such as prasinophytes and prymnesiophytes play an important role in oceanic carbon cycling, and proteins from the prasinophytes are abundant in particulate organic matter and dissolved organic matter collected from both the surface and mesopelagic layers in the SCS (Dong et al. 2010, Wang et al. 2011). Moreover, prasinophytes sequences have been found in the sedimenting material at 200 and $500 \mathrm{~m}$ in the eastern subtropical Atlantic (Amacher et al. 2009). The picoeukaryotic phytoplankton might play a more important role in primary production, and contribute more to oceanic carbon export from the surface ocean than is currently recognized.

Acknowledgements. We sincerely thank J. Hu, J. Zhu, and Z. Sun for providing the CTD data and Y. Zhang, Y. Xu, and L. Wang for providing the nutrient data. We also thank Dr. K. Chiang and Dr. B. Chen for their useful comments on the manuscript. We acknowledge organization of the cruise by the captain and crew of the RV 'Dongfanghong 2 ' and the chief scientists M. Dai, P. Cai, and W. Zhai. This work was supported by the Natural Science Foundation of China (NSFC 40925018, 41176112), National Basic Research Program ('973' program) of China through Grant 2009CB 421203 (CHOICE-C), and the Ocean Public Welfare Scientific Research Project, State Oceanic Administration People's Republic of China (NO. 201005015, 201105021, GASI03-01-02-03). Professor J. Hodgkiss of The University of Hong Kong is thanked for his help with the English.

\section{LITERATURE CITED}

Altschul SF, Gish W, Miller W, Myers EW, Lipman DJ (1990) Basic local alignment search tool. J Mol Biol 215:403-410 Amacher J, Neuer S, Anderson I, Massana R (2009) Molecular approach to determine contributions of protist community to particle flux. Deep-Sea Res I 56:2206-2215

Balzano S, Marie D, Gourvil P, Vaulot D (2012) Composition of the summer photosynthetic pico and nanoplankton communities in the Beaufort Sea assessed by T-RFLP and sequences of the 18S rRNA gene from flow cytometry sorted samples. ISME J 6:1480-1498

Blanchot J, André JM, Navarette C, Neveux J, Radenae MH (2001) Picophytoplankton in the equatorial Pacific: vertical distributions in the warm pool and in the high nutrient low chlorophyll conditions. Deep-Sea Res I 48:297-314

$>$ Caron DA, Countway PD, Savai P, Gast RJ and others (2009) Defining DNA-based operational taxonomic units for microbial-eukaryote ecology. Appl Environ Microbiol 75: 5797-5808

Castresana J (2000) Selection of conserved blocks from multiple alignments for their use in phylogenetic analysis. Mol Biol Evol 17:540-552

> Chen Y, Wang N, Zhang P, Zhou H, Qu L (2002) Molecular evidence identifies bloom-forming Phaeocystis (Prymnesiophyta) from coastal waters of southeast China as Phaeocystis globosa. Biochem Syst Ecol 30:15-22

Chen YL, Chen H, Karl DM, Takahashi M (2004) Nitrogen modulates phytoplankton growth in spring in the South China Sea. Cont Shelf Res 24:527-541

> Chen B, Wang L, Song S, Huang B and others (2011) Comparisons of picophytoplankton abundance, size, and fluorescence between summer and winter in northern South China Sea. Cont Shelf Res 31:1527-1540

Collado-Fabbri S, Vaulot D, Ulloa O (2011) Structure and seasonal dynamics of the eukaryotic picophytoplankton community in a wind-driven coastal upwelling ecosystem. Limnol Oceanogr 56:2334-2346

> Countway PD, Caron DA (2006) Abundance and distribution of Ostreococcus sp. in the San Pedro Channel, California, as revealed by quantitative PCR. Appl Environ Microbiol 72:2496-2506

Countway PD, Gast RJ, Savai P, Caron DA (2005) Protistan diversity estimates based on 18S rDNA from seawater incubations in the Western North Atlantic. J Eukaryot Microbiol 52:95-106

> Cuvelier ML, Allen AE, Monier A, McCrow JP and others (2010) Targeted metagenomics and ecology of globally important uncultured eukaryotic phytoplankton. Proc Natl Acad Sci USA 107:14679-14684

> Demir-Hilton E, Sudek S, Cuvelier ML, Gentemann CL and others (2011) Global distribution patterns of distinct clades of the photosynthetic picoeukaryote Ostreococcus. ISME J 5:1095-1107 
Dong HP, Wang DZ, Dai MH, Hong HS (2010) Characterization of particulate organic matter in the water column of the South China Sea using a shotgun proteomic approach. Limnol Oceanogr 55:1565-1578

> Du C, Liu Z, Dai M, Kao SJ and others (2013) Impact of the Kuroshio intrusion on the nutrient inventory in the upper northern South China Sea: insights from an isopycnal mixing model. Biogeosciences 10:6419-6432

> DuRand MD, Olson RJ, Chisholm SW (2001) Phytoplankton population dynamics at the Bermuda Atlantic Time-series station in the Sargasso Sea. Deep-Sea Res II 48:1983-2003

Fenchel T, Finlay BJ (2004) The ubiquity of small species: patterns of local and global diversity. BioScience 54: 777-784

- Finlay BJ (2002) Global dispersal of free-living microbial eukaryote species. Science 296:1061-1063

> Fuller NJ, Campbell C, Allen DJ, Pitt FD and others (2006) Analysis of photosynthetic picoeukaryote diversity at open ocean sites in the Arabian Sea using a PCR biased towards marine algal plastids. Aquat Microb Ecol 43:79-93

Furuya K, Marumo R (1983) The structure of the phytoplankton community in the subsurface chlorophyll maxima in the western North Pacific Ocean. J Plankton Res 5: 393-406

Furuya K, Hayashi M, Yabushita Y (1998) HPLC determination of phytoplankton pigments using N,N-dimethylformamide. J Oceanogr 54:199-203

> Giovannoni SJ, DeLong EF, Olsen GJ, Pace NR (1988) Phylogenetic group-specific oligonucleotide probes for identification of single microbial cells. J Bacteriol 170:720-726

Green JC (1991) Phagotrophy in prymnesiophyte flagellates. In: Patterson DJ, Larsen J (eds) The biology of free-living heterotrophic flagellates. Syst Assoc Spec Vol 45:401-414

Guillou L, Moon-Van der Staay SY, Claustre H, Partensky F, Vaulot D (1999) Diversity and abundance of Bolidophyceae (Heterokonta) in two oceanic regions. Appl Environ Microbiol 65:4528-4536

Guillou L, Eikrem W, Chrétiennot-Dinet MJ, Le Gall F and others (2004) Diversity of picoplanktonic prasinophytes assessed by direct nuclear SSU rDNA sequencing of environmental samples and novel isolates retrieved from oceanic and coastal marine ecosystems. Protist 155: 193-214

Harrison PJ, Yin K, Lee JHW, Gan J, Liu H (2008) Physicalbiological coupling in the Pearl River Estuary. Cont Shelf Res 28:1405-1415

Hernández-Becerril DU, Aquino-Cruz A, Salas-De-León DA, Signoret-Poillon M, Monreal-Gómez MA (2012) Studies on picophytoplankton in the southern Gulf of Mexico: pigment analysis and potential importance of the picoeukaryote Prasinophyte Micromonas pusilla. Mar Biol Res 8:331-340

> Hu J, Zheng Q, Sun Z, Tai CK (2012) Penetration of nonlinear Rossby eddies into South China Sea evidenced by cruise data. J Geophys Res 117, C03010, doi:10.1029/ 2011JC007525

- Huelsenbeck JP, Ronquist F (2001) MRBAYES: Bayesian inference of phylogeny. Bioinformatics 17:754-755

> Jardillier L, Zubkov MV, Pearman J, Scanlan DJ (2010) Significant $\mathrm{CO}_{2}$ fixation by small prymnesiophytes in the subtropical and tropical northeast Atlantic Ocean. ISME J 4:1180-1192

Kirkham AR, Jardillier LE, Holland R, Zubkov MV, Scanlan DJ (2011) Analysis of photosynthetic picoeukaryote community structure along an extended Ellett line transect in the northern North Atlantic reveals a dominance of novel prymnesiophyte and prasinophyte phylotypes. Deep-Sea Res I 58:733-744

> Kirkham AR, Lepère C, Jardillier LE, Not F and others (2013) A global perspective on marine photosynthetic picoeukaryote community structure. ISME J 7:922-936

> Latasa M, Scharek R, Le Gall F, Guillou L (2004) Pigment suites and taxonomic groups in Prasinophyceae. J Phycol 40:1149-1155

> Li WKW (1994) Primary production of prochlorophytes, cyanobacteria, and eucaryotic ultraphytoplankton: measurements from flow cytometric sorting. Limnol Oceanogr 39:169-175

> Li LY, Lin D, Chen JH, Wu SH and others (2010) Diversity and distribution of planktonic protists in the northern South China Sea. J Plankton Res 33:445-456

> Liang WD, Yang YJ, Tang TY, Chuang WS (2008) Kuroshio in the Luzon Strait. J Geophys Res 113, C08048, doi: 10.1029/2007JC004609

> Litchman E, Klausmeier CA, Schofield OM, Falkowski P (2007) The role of functional traits and trade-offs in structuring phytoplankton communities: scaling from cellular to ecosystem level. Ecol Lett 10:1170-1181

Liu KK, Chao SY, Shaw PT, Gong GC and others (2002) Monsoon-forced chlorophyll distribution and primary production in the South China Sea: observations and a numerical study. Deep-Sea Res I 49:1387-1412

> Liu H, Chang J, Tseng CM, Wen LS, Liu KK (2007) Seasonal variability of picoplankton in the Northern South China Sea at the SEATS station. Deep-Sea Res II 54:1602-1616

Liu H, Probert I, Uitz J, Claustre H and others (2009) Extreme diversity in noncalcifying haptophytes explains a major pigment paradox in open oceans. Proc Natl Acad Sci USA 106:12803-12808

> Lovejoy C, Vincent WF, Bonilla S, Roy S and others (2007) Distribution, phylogeny, and growth of cold-adapted picoprasinophytes in Arctic Seas. J Phycol 43:78-89

> Mackey MD, Mackey DJ, Higgins HW, Wright SW (1996) CHEMTAX - a program for estimating class abundances from chemical markers: application to HPLC measurements of phytoplankton. Mar Ecol Prog Ser 144: 265-283

> Mackey DJ, Higgins HW, Mackey MD, Holdsworth D (1998) Algal class abundances in the western equatorial Pacific: estimation from HPLC measurements of chloroplast pigments using CHEMTAX. Deep-Sea Res I 45:1441-1468

Mackey DJ, Blanchot J, Higgins HW, Neveux J (2002) Phytoplankton abundances and community structure in the equatorial Pacific. Deep-Sea Res II 49:2561-2582

> Marie D, Zhu F, Balagué V, Ras J, Vaulot D (2006) Eukaryotic picoplankton communities of the Mediterranean Sea in summer assessed by molecular approaches (DGGE, TTGE, QPCR). FEMS Microbiol Ecol 55:403-415

Marin B, Melkonian M (2010) Molecular phylogeny and classification of the Mamiellophyceae class. nov. (Chlorophyta) based on sequence comparisons of the nuclear- and plastid-encoded rRNA operons. Protist 161: 304-336

McDonald SM, Sarno D, Scanlan DJ, Zingone A (2007) Genetic diversity of eukaryotic ultraphytoplankton in the Gulf of Naples during an annual cycle. Aquat Microb Ecol 50:75-89

Michaels AF, Silver MW (1988) Primary production, sinking fluxes and the microbial food web. Deep-Sea Res 35: $473-490$ 
Moon-van der Staay SY, van der Staay GWM, Guillou L, Vaulot D and others (2000) Abundance and diversity of prymnesiophytes in the picoplankton community from the equatorial Pacific Ocean inferred from 18S rDNA sequences. Limnol Oceanogr 45:98-109

Moon-van der Staay SY, De Wachter R, Vaulot D (2001) Oceanic 18S rDNA sequences from picoplankton reveal unsuspected eukaryotic diversity. Nature 409:607-610

> Ning X, Chai F, Xue H, Cai Y and others (2004) Physical-biological oceanographic coupling influencing phytoplankton and primary production in the South China Sea. J Geophys Res 109, C10005, doi:10.1029/2004JC002365

> Not F, Simon N, Biegala IC, Vaulot D (2002) Application of fluorescent in situ hybridization coupled with tyramide signal amplification (FISH-TSA) to assess eukaryotic picoplankton composition. Aquat Microb Ecol 28:157-166

> Not F, Latasa M, Marie D, Cariou T and others (2004) A single species, Micromonas pusilla (Prasinophyceae), dominates the eukaryotic picoplankton in the Western English Channel. Appl Environ Microbiol 70:4064-4072

> Not F, Massana R, Latasa M, Marie D and others (2005) Late summer community composition and abundance of photosynthetic picoeukaryotes in Norwegian and Barents Seas. Limnol Oceanogr 50:1677-1686

> Not F, Zapata M, Pazos Y, Campaña E, Doval M, Rodríguez F (2007) Size-fractionated phytoplankton diversity in the NW Iberian coast: a combination of microscopic, pigment and molecular analyses. Aquat Microb Ecol 49:255-265

Not F, Latasa M, Scharek R, Viprey M and others (2008) Protistan assemblages across the Indian Ocean, with a specific emphasis on the picoeukaryotes. Deep-Sea Res I 55: 1456-1473

> Not F, del Campo J, Balagué V, de Vargas C, Massana R (2009) New insights into the diversity of marine picoeukaryotes. PLoS ONE 4:e7143

> O'Kelly CJ, Sierachi ME, Their EC, Hobson I (2003) A transient bloom of Ostreococcus (Chlorophyta, Prasinophyceae) in West Neck Bay, Long Island, New York. J Phycol 39:850-854

- Pérez V, Fernández E, Marañón E, Serret P and others (2005) Latitudinal distribution of microbial plankton abundance, production, and respiration in the equatorial Atlantic in autumn 2000. Deep-Sea Res I 52:861-880

Richardson TL, Jackson GA (2007) Small phytoplankton and carbon export from the surface ocean. Science 315: 838-840

Rodríguez F, Derelle E, Guillou L, Le Gall F and others (2005) Ecotype diversity in the marine picoeukaryote Ostreococcus (Chlorophyta, Prasinophyceae). Environ Microbiol 7:853-859

Schlitzer R (2011) Ocean data view. Available at http://odv. awi.de

Schloss PD, Westcott SL, Ryabin T, Hall JR and others (2009) Introducing mothur: open-source, platform-independent, community-supported software for describing and comparing microbial communities. Appl Environ Microbiol 75:7537-7541

Shaw PT, Chao SY (1994) Surface circulation in the South China Sea. Deep-Sea Res I 41:1663-1683

Shi XL, Marie D, Jardillier L, Scanlan DJ, Vaulot D (2009) Groups without cultured representatives dominate eukaryotic picophytoplankton in the oligotrophic South East Pacific Ocean. PLoS ONE 4:e7657

Sievers F, Wilm A, Dineen DG, Gibson TJ and others (2011) Fast, scalable generation of high-quality protein multiple sequence alignments using Clustal Omega. Mol Syst Biol 7:539

Simon N, Le Bot N, Marie D, Partensky F, Vaulot D (1995) Fluorescent in situ hybridization with rRNA-targeted oligonucleotide probes to identify small phytoplankton by flow cytometry. Appl Environ Microbiol 61:2506-2513

Simon N, Campbell L, Örnolfsdottir E, Groben R and others (2000) Oligonucleotide probes for the identification of three algal groups by dot blot and fluorescent whole-cell hybridization. J Eukaryot Microbiol 47:76-84

Šlapeta J, López-García P, Moreira D (2006) Global dispersal and ancient cryptic species in the smallest marine eukaryotes. Mol Biol Evol 23:23-29

Tamura K, Peterson D, Peterson N, Stecher G and others (2011) MEGA5: molecular evolutionary genetics analysis using maximum likelihood, evolutionary distance, and maximum parsimony methods. Mol Biol Evol 28: 2731-2739

Treusch AH, Demir-Hilton E, Vergin KL, Worden AZ and others (2012) Phytoplankton distribution patterns in the northwestern Sargasso Sea revealed by small subunit rRNA genes from plastids. ISME J 6:481-492

> Vaulot D, Le Gall F, Marie D, Guillou L, Partensky F (2004) The Roscoff Culture Collection (RCC): A collection dedicated to marine picoplankton. Nova Hedwigia 79:49-70

Viprey M, Guillou L, Ferréol M, Vaulot D (2008) Wide genetic diversity of picoplanktonic green algae (Chloroplastida) in the Mediterranean Sea uncovered by a phylumbiased PCR approach. Environ Microbiol 10:1804-1822

> Wang DZ, Dong HP, Xie ZX, Dai MH, Hong HS (2011) Metaproteomic characterization of dissolved organic matter in the water column of the South China Sea. Limnol Oceanogr 56:1641-1652

Welschmeyer NA (1994) Fluorometric analysis of chlorophyll a in the presence of chlorophyll b and pheopigments. Limnol Oceanogr 39:1985-1992

Worden AZ (2006) Picoeukaryote diversity in coastal waters of the Pacific Ocean. Aquat Microb Ecol 43:165-175

Worden AZ, Nolan JK, Palenik B (2004) Assessing the dynamics and ecology of marine picophytoplankton: the importance of the eukaryotic component. Limnol Oceanogr 49:168-179

> Worden AZ, Lee JH, Mock T, Rouzé P and others (2009) Green evolution and dynamic adaptations revealed by genomes of the marine picoeukaryotes Micromonas. Science 324:268-272

Xu J, Yin K, He L, Yuan Z and others (2008) Phosphorus limitation in the northern South China Sea during late summer: influence of the Pearl River. Deep-Sea Res I 55: 1330-1342

Yuan J, Chen MY, Shao P, Zhou H and others (2004) Genetic diversity of small eukaryotes from the coastal waters of Nansha Islands in China. FEMS Microbiol Lett 240: 163-170

> Zhu F, Massana R, Not F, Marie D, Vaulot D (2005) Mapping of picoeucaryotes in marine ecosystems with quantitative PCR of the 18S rRNA gene. FEMS Microbiol Ecol 52: 79-92

Zubkov MV, Tarran GA (2008) High bacterivory by the smallest phytoplankton in the North Atlantic Ocean. Nature 455:224-226

Zubkov MV, Sleigh MA, Tarran GA, Burkill PH, Leakey RJG (1998) Picoplanktonic community structure on an Atlantic transect from $50^{\circ} \mathrm{N}$ to $50^{\circ} \mathrm{S}$. Deep-Sea Res I 45 : 1339-1355 